\title{
Protection Systems for Reinforced Concrete with Corrosion Inhibitors
}

\author{
Angeliki Zacharopoulou, Eugenia Zacharopoulou, George Batis \\ Department of Materials Science and Engineering, School of Chemical Engineering, National Technical \\ University of Athens (NTUA), Athens, Greece \\ Email: aggeliki.zaxaropoulou@gmail.com
}

Received 22 August 2014; revised 22 September 2014; accepted 21 October 2014

Copyright (C) 2014 by authors and Scientific Research Publishing Inc.

This work is licensed under the Creative Commons Attribution International License (CC BY).

http://creativecommons.org/licenses/by/4.0/

(c) (i) Open Access

\section{Abstract}

This paper examines the use of corrosion inhibitors in order to protect the reinforcement of concrete. For this purpose mortar specimens were constructed with or without corrosion inhibitors and were partially immersed in sodium chloride. Corrosion inhibitors were used as admixture into concrete and were sprayed on the external surface of mortar specimens. In all mortar specimens, electric junction between reinforcements was achieved. The methods that were used for the evaluation of the reinforcement corrosion in concrete, included half-cell potential measurements, polarization curves of reinforced rebars and mass loss of the reinforcement. Finally, the durability of concrete after the use of corrosion inhibitors was also examined.

\section{Keywords}

\section{Reinforced, Corrosion Inhibitors, Corrosion Protection}

\section{Introduction}

The rapid deterioration of concrete structures due to reinforcement corrosion has become a growing problem in recent years, effective to all kind of constructions, especially those located near to marine areas. Chloride ions are one of the main factors threatening concrete structures and in order to delay their penetration and hence to prolong the service life of concrete structures, surface treatment such as coating is commonly used. For these reasons, it has been developed methods to protect steel reinforcement from corrosion as corrosion inhibitors, cathodic protection, etc.

In the field of science and technical material people have developed a method of protecting the steel reinforcement from atmospheric corrosion using corrosion inhibitors. One way of coping is the use of corrosion in- 
hibitors. These are organic or inorganic salts, admixtures of concrete used in order to protect the reinforcements. The mechanism of influence of these admixtures is complex and varies depending on the salt. Also, their use presents a major drawback to the change in certain physical properties of concrete (compressive strength, reduction hardened of cement) and their unproven effectiveness [1].

Corrosion inhibitors act:

-In ascending and descending portion of the electrochemical reaction of corrosion and slow down significantly and their energy lies in their interface metal corrosive environment.

-In the process of the corrosive action with a chemical action and their energy extends across the corrosive environment. For the corrosion inhibitors, of the first case, the first step is the sorption on the metal surface.

Corrosion of reinforcing steel probably is the most widespread damage mechanism to which reinforced concrete structures are subjected. Due to carbonation and chloride penetration the passive layer around the reinforcing steel is destroyed, leaving the steel bar unprotected to the effect of corrosion. One method of protection is the corrosion inhibitors [2].

Reinforced concrete is currently the most common material used for the construction of the load bearing elements of structures. Although this composite material performs exceptionally well, it has been noted that during the life span of reinforced concrete structures, which often exceeds 100 years, a gradual damage accumulation takes place. One of the most influential factors of this damage has been attributed to the corrosion of steel reinforcement. Recently, the degradation of the load bearing ability of steel reinforcement has been an issue under research by several researchers worldwide. Yet to date, the technological importance of this degradation caused by corrosion damage cannot be assessed to a satisfactory degree, mainly due to the lack of relevant experimental studies. Similarly, the physical mechanisms which contribute to the degradation have not been totally resolved [3].

The purpose of this study is to examine the durability of steel reinforcement with that protection to mortar in conditions of corrosion, as well as to examine the effect and efficacy of diffused organic corrosion inhibitor, in quantities less than the amount of $4 \%$ of concrete, on the protection offered as either additive into the concrete or as sprayed of the external surface of mortar specimens. As a corrosive environment was used in salt environment [4].

\section{Experimental Investigation}

Three groups of specimens were constructed and each one of them consisted of 6 specimens. Each specimen was cube formed in $100 \mathrm{~mm} \times 100 \mathrm{~mm}$ and included 4 rebars at equal distances from the centre of the specimen. Steel rebars were embedded $80 \mathrm{~mm}$ deep into the mortar and consequently $20 \mathrm{~mm}$ exerted. In order to receive electrochemical measurements, a copper wire was enwrapped to each steel rebar. The mixture of cement mortar included one type of corrosion inhibitor in used as either admixture into the concrete or as sprayed of the external surface of mortar specimens. Also, a group of steel rebars were embedded in specimens of cement mortar without including corrosion inhibitors, which is the basis for comparison of results of measurements. The specimens were partially immersed in $3.5 \mathrm{wt} \% \mathrm{NaCl}$ solution and specimens for each group were electrochemically investigated regarding their corrosion behaviour. Their mean values are illustrated in the corresponding figures and tables [5].

\subsection{Materials}

The materials used in the test program consisted of the following:

Cement II 32.5N, Greek quarry sand of $250 \mu \mathrm{m}-4 \mathrm{~mm}$ maximum grain dimension and drinkable water from NTUA water supply network, appropriate for preparing specimens according to ELOT 452 were used for the construction of the specimens. The $\mathrm{pH}$ value of the pore solution in sound OPC concrete is normally up to 13 .

The ratio of the cement with aggregates and water were 1:3:0.5.

The ratio of organic inhibitor was $0.4 \mathrm{gr} / 100 \mathrm{gr}$ cement.

Inhibitors: One organic inhibitor was used. The chemical type of corrosion inhibitor consisted of cyclohexylammonium benzoate in ratio 50\% and disopropylammonium benzoate in ratio 50\% [6]. Cement mortar specimens were partially immersed in $3.5 \mathrm{wt} \% \mathrm{NaCl}$ solution (Table 1). Steel rebars type B500c were used, having $10 \mathrm{~mm}$ nominal diameter and $100 \mathrm{~mm}$ length (Table 2). The rebars were made according to Greek specifications of Hellenic Organization for Standardization ELOT 1421-37 [7]. 
Table 1. Chemical composition of Portland cement.

\begin{tabular}{cccccccccc}
\hline $\mathrm{SiO}_{2}$ & $\mathrm{Al}_{2} \mathrm{O}_{3}$ & $\mathrm{Fe}_{2} \mathrm{O}_{3}$ & $\mathrm{CaO}$ & $\mathrm{MgO}$ & $\mathrm{K}_{2} \mathrm{O}$ & $\mathrm{Na}_{2} \mathrm{O}$ & $\mathrm{SO}_{3}$ & $\mathrm{CaO}_{(f)}$ & $\mathrm{LOI}$ \\
\hline 20.67 & 4.99 & 3.18 & 63.60 & 2.73 & 0.37 & 0.29 & 2.414 & 2.41 & 2.52 \\
\hline
\end{tabular}

Table 2. Chemical composition of black steel B500c.

\begin{tabular}{ccccccccccc}
\hline $\mathrm{C}$ & $\mathrm{Mn}$ & $\mathrm{S}$ & $\mathrm{P}$ & $\mathrm{Si}$ & $\mathrm{Ni}$ & $\mathrm{Cr}$ & $\mathrm{Cu}$ & $\mathrm{V}$ & $\mathrm{Mo}$ \\
\hline 0.18 & 0.99 & 0.047 & 0.023 & 0.15 & 0.09 & 0.09 & 0.21 & 0.002 & 0.021 \\
\hline
\end{tabular}

\subsection{Specimens}

To evaluate the corrosion behavior of rebars, cement mortars with corrosion inhibitors were constructed. Three groups of specimens were constructed and each one of them consisted of 6 specimens. Steel rebars type B500C (ELOT 1421-37) were used, having $10 \mathrm{~mm}$ nominal diameter and $100 \mathrm{~mm}$ length. Each specimen was cube formed in $100 \mathrm{~mm} \times 100 \mathrm{~mm}$ and included 4 rebars at equal distances from the centre of the specimen. For all specimens, the ratio cement/water/sand was 1:0.5:3. The rebars were embedded $80 \mathrm{~mm}$ deep into the mortar and consequently $20 \mathrm{~mm}$ exerted. The specimens remained molded for $24 \mathrm{~h}$ at ambient conditions $\left(25^{\circ} \mathrm{C}\right.$ and $50 \%$ $\mathrm{RH})$ in the laboratory. After removing the cast they were stored in the curing room $\left(20^{\circ} \mathrm{C}, 99 \% \mathrm{RH}\right)$ for $24 \mathrm{~h}$ and thereafter were left to dry for 7 days under laboratory conditions $\left(25^{\circ} \mathrm{C}\right.$ and $\left.50 \% \mathrm{RH}\right)$. In order to receive electrochemical measurements, a copper wire was enwrapped to each steel rebar [8].

- Group A did not include corrosion inhibitor. Group A, consists of 6 specimens and each one of them has 4 rebars.

- Group B included corrosion inhibitor as sprayed of the external surface of mortar specimens. Group B, consists of 6 specimens and each one of them has 4 rebars.

- Group C included corrosion inhibitor as admixture into the concrete. Group C, consists of 6 specimens and each one of them has 4 rebars.

\subsection{Items of Investigation}

The methods, with which was tested the corrosion of reinforcement in concrete, were:

- The measurement of half cell potential versus a saturated calomel reference electrode in contact with the surface of each specimen.

- Polarization curves of reinforced rebars.

- Mass loss of steel reinforcement.

In addition, after curing of 28 days, plain concrete specimens were tested for compressive strength. The compressive strength was measured with ultrasonic method and also with test hammer.

\section{Analytical Procedure or Measurement Methods}

\subsection{Half Cell Potential Measurements}

Half cell potential tests were conducted, following the ASTM C876 [9] guidelines, to determine the likelihood of active corrosion. The half cell potential difference between the working electrodes and a saturated calomel reference electrode (SCE) placed in the solution was measured using a high-impedance voltmeter.

\subsection{Mass Loss of Steel Rebars}

At the end of the exposure period, the mortar specimens were carefully broken and the embedded steel bars were recovered from them. They were visually examined to assess their corrosion state qualitatively and then cleaned in an aqueous solution of $\mathrm{HCl}$ containing a proprietary corrosion inhibitor [10] which served to dissolve the corrosion products according to ISO/DIS 8407.3 [11]. The average mass loss was calculated from the difference between the initial and the final mass of each steel rebar. By comparing the mass loss depending on the exposure time in corrosive medium weighted in the laboratory with accuracy of $0.1 \mathrm{mg}$. 


\section{Experimental Results and Discussion}

\subsection{Half-Cell Potential Measurements}

Half-cell potential measurements of steel rebars are the most typical procedure to the routine inspection of reinforced concrete structures regarding the corrosion trend of the samples. Potential readings are highly influenced by the surface treatment of the specimens which causes changes in their resistivity, as long as the constituents of the cement mortars remain the same. Figure 1 presents the corrosion potentials as a function of exposure period for cement mortars specimens which included corrosion inhibitor admixture into the concrete, sprayed of the external surface of mortar specimens and without corrosion inhibitor and immersed in $3.5 \mathrm{wt} \% \mathrm{NaCl}$ solution.

Figure 1 shows the comparison of averages of the half cell potential of Groups A, B and C. It is observed that the two groups (B, C), containing corrosion inhibitors, have greater half cell potential than Group A, containing no corrosion inhibitor. Also, Group C, which has corrosion inhibitor as admixture, has a greater half cell potential than Group B, which has corrosion inhibitor as sprayed. So Group C has fewer tendencies to corrode since it has less half cell potential compared with Groups A and B.

From the above results, it is obvious that the corrosion inhibitor has the tendency to protect the rebars from the corrosion.

\subsection{Linear Polarization Technique}

Linear polarization technique is a corrosion monitoring method that allows corrosion rates to be measured directly, in real time. The technique is rapid and non-intrusive, requiring only a connection to the reinforcing steel. In LPR measurements the reinforcing steel is perturbed by a small amount from its equilibrium potential. This can be accomplished potentiostatically by changing the potential of the reinforcing steel by a fixed amount, $\Delta E$, and monitoring the current decay, $\Delta I$, after a fixed time. The polarization resistance, $R_{p}$, of the steel is then calculated from the equation [2].

$$
R_{p}=\frac{\Delta E}{\Delta I}
$$

From which the corrosion rate, $I_{\text {corr }}$, can then be calculated

$$
I_{\text {corr }}=\frac{\beta_{\alpha} \cdot \beta_{c}}{2.303 \cdot\left(\beta_{\alpha}+\beta_{c}\right)} \cdot \frac{1}{R_{p}}=\frac{B}{R_{p}}
$$

where $\beta_{\alpha} \cdot \beta_{c}$ are the anodic and cathodic Tafel slopes respectively and $R_{p}$ is the polarization resistance (Ohm). For Stern-Geary constant B a value of $26 \mathrm{mV}$ has been adopted for active corroding steel bars and $52 \mathrm{mV}$ for passive conditions. In order to determine the corrosion current density, $i_{\text {corr }}$, the surface area, $A$, of steel that has been polarized needs to be accurately known:

$$
i_{\text {corr }}=\frac{I_{\text {corr }}}{A}
$$

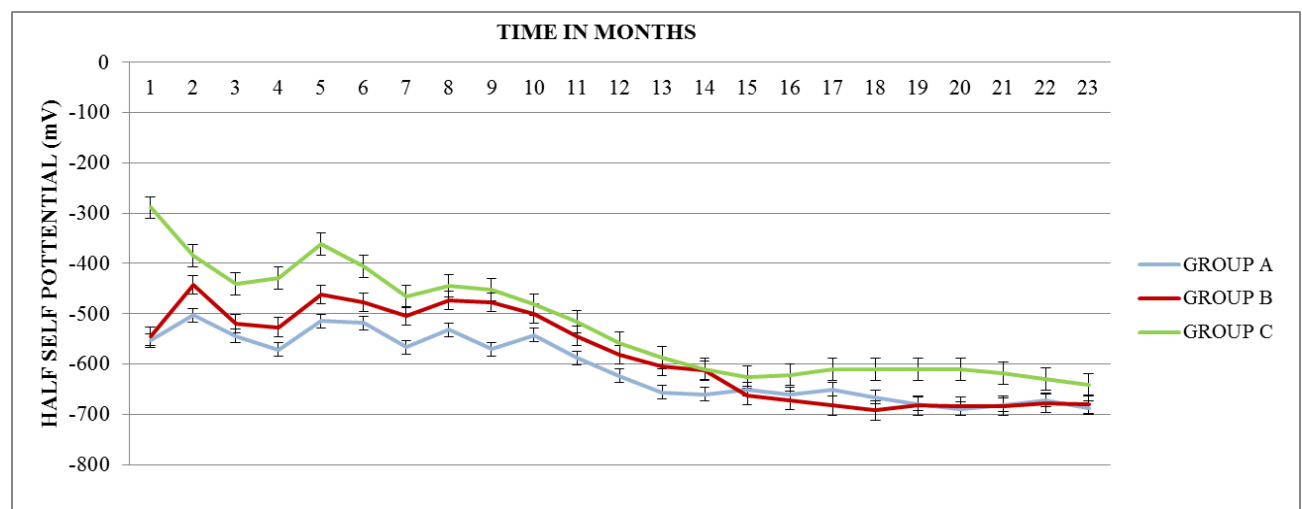

Figure 1. Average of half cell potential measurements of specimens of Groups A, B and C versus time. 
Obtained $R_{p}$ values are highly correlated with a number of factors, including surface treatment, corrosive environment and the materials that were used for the construction of the specimens. In the present study the corrosive environment as well as the materials of the specimens remained stable and consequently all changes to $R_{p}$ values are due to differences in the surfaces treatment.

Figure 2 shows the comparison of electrochemical mass loss of Groups A, B and C. It is noticed that the two groups $\mathrm{B}$ and $\mathrm{C}$, containing corrosion inhibitors, have better behaviour in the corrosion from Group A, containing no corrosion inhibitor [12].

Figure 3 shows the comparison of electrochemical mass loss of Groups B and C. Group C, which has corrosion inhibitor as admixture, has slightly better behaviour in the corrosion than Group B, which has corrosion inhibitor as sprayed. Finally, it is obvious that Group C resists more than Group A and B.

\subsection{Mass Loss of Steel Rebars}

During the exposure period, the mortar specimens were carefully broken and the embedded steel bars were recovered from them. The average mass loss was calculated from the difference between the initial and the final mass of each steel rebar [4].

Figure 4 shows the mass loss of rebars after the breaking of specimens of Groups A, B, C. Initially, it is measured the mass of the rebars before they embedded in specimens, after 18 months the mortar specimens were carefully broken, cleaned the rebars in order to dissolve the corrosion products and cementitious debris and measured their mass. The average mass loss was calculated from the difference between the initial and the final mass of each steel bar. By comparing the mass loss of rebars, it is obvious that Group $\mathrm{C}$ has the less mass loss than Group B and Group B has the less mass loss than Group A (see Figure 4).

Assuming that Group A is 100\% of mass loss, Group B has mass loss $72.20 \%$ and Group C has 60.33\% (Ratio Group A: Group B).

Consequently the protection rate of Group B was $27.80 \%$ and Group C was $39.67 \%$. The degree of protection resulting from the rate of mass loss compared with the group A which contains no addition.

The diagram linear polarization shows that at 18 months Group B has 10\% mass loss and 5\% for Group C.

Consequently the protection rate of Group B was $90 \%$ and $95 \%$ for Group C.

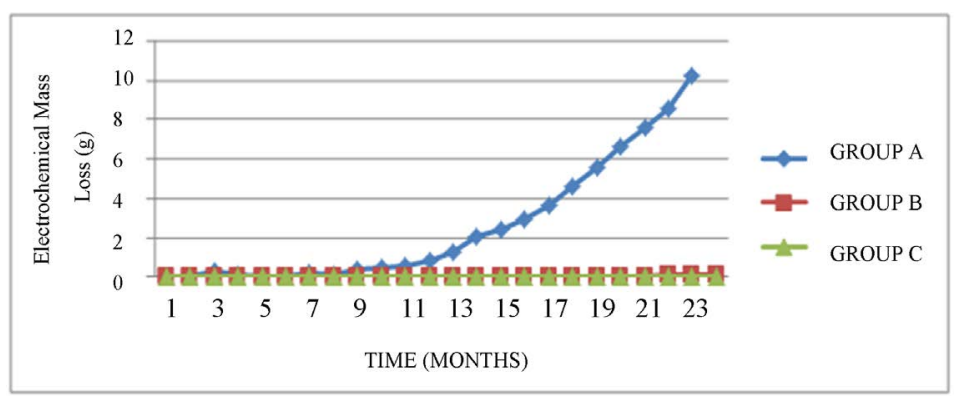

Figure 2. Electrochemical mass loss of Groups A, B and C versus time.

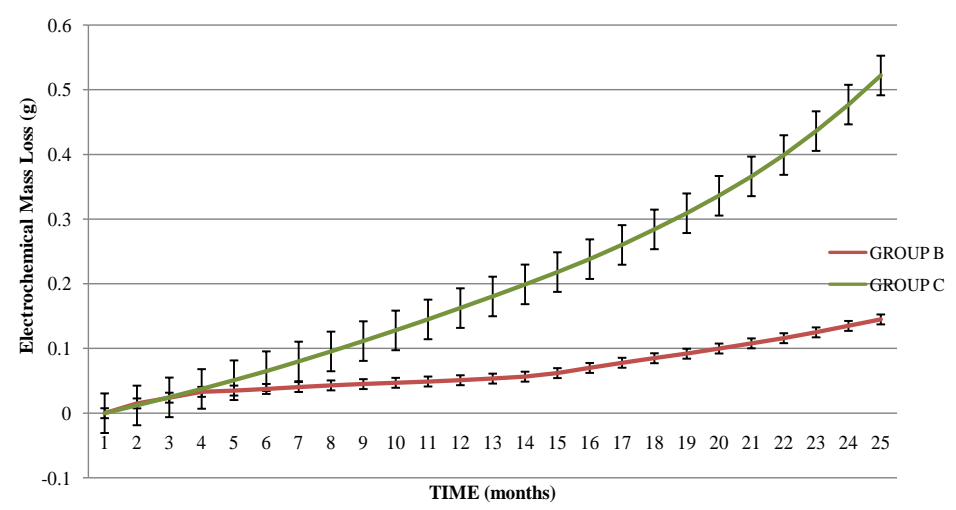

Figure 3. Electrochemical mass loss of Groups B and C versus time. 
Furthermore, the compressive strength of specimens with and without corrosion inhibitor was measured. The measurements were for the specimens without corrosion inhibitor $14.5 \mathrm{MPa}$, for the specimens with corrosion inhibitor as admixture 14.4 MPa (see Table 3). From these measurements, it is obvious that the used of corrosion inhibitor has not changed the compressive strength.

Finally, in this study, the period that examined the specimens are relatively small. Electrochemical measurements should be conducted for a longer period of exposure time so that it is clear the progress of corrosion of rebars [13].

\section{Discussion}

Action of organic corrosion inhibitor:

$$
\begin{gathered}
\mathrm{R}_{2} \mathrm{~N}_{2} \mathrm{NO}_{2} \rightarrow \mathrm{R}_{2} \mathrm{NH}_{2}^{+}+\mathrm{NO}_{2}^{-}+\mathrm{OH}^{-}+\mathrm{H}^{+} \rightarrow \mathrm{R}_{2} \mathrm{NH}+\mathrm{HNO}_{2} \\
\mathrm{R}_{2} \mathrm{~N}_{2} \mathrm{COOR}^{\prime} \stackrel{\text { нон }}{\longrightarrow} \mathrm{R}_{2} \mathrm{NH}_{2}^{+}+\mathrm{R}^{\prime} \mathrm{COO}^{-}+\mathrm{OH}^{-}+\mathrm{H}^{+} \rightarrow \mathrm{R}_{2} \mathrm{NH}+\mathrm{R}^{\prime} \mathrm{COOH}
\end{gathered}
$$

A number of commercial corrosion inhibitors are marketed for use in reinforced concrete. They are added to inhibit the action of chloride ion, which is generally considered to be the corrosive agent. Corrosion inhibitors are admixtures into concrete or spayed on the surface of concrete which usually do more than just corrosion inhibitor. They may influence initial set, later strength gain or other properties. The effects they produce in the field depend on conditions there — which may not be identical to conditions used in the laboratory [14][15].

Benzoate ion is itself a corrosion inhibitor, especially at high $\mathrm{pH}$, probably by adsorbing on active sites.

The use of an alkanolamine-based migrating inhibitor as supplementary anticorrosion system appears to extend the rehabilitation and protection properties of a low-porosity repair mortar [16]. For the measurements of this study is clear that sprayed corrosion inhibitor creates high percent protection (see Figure 3 and Figure 4).

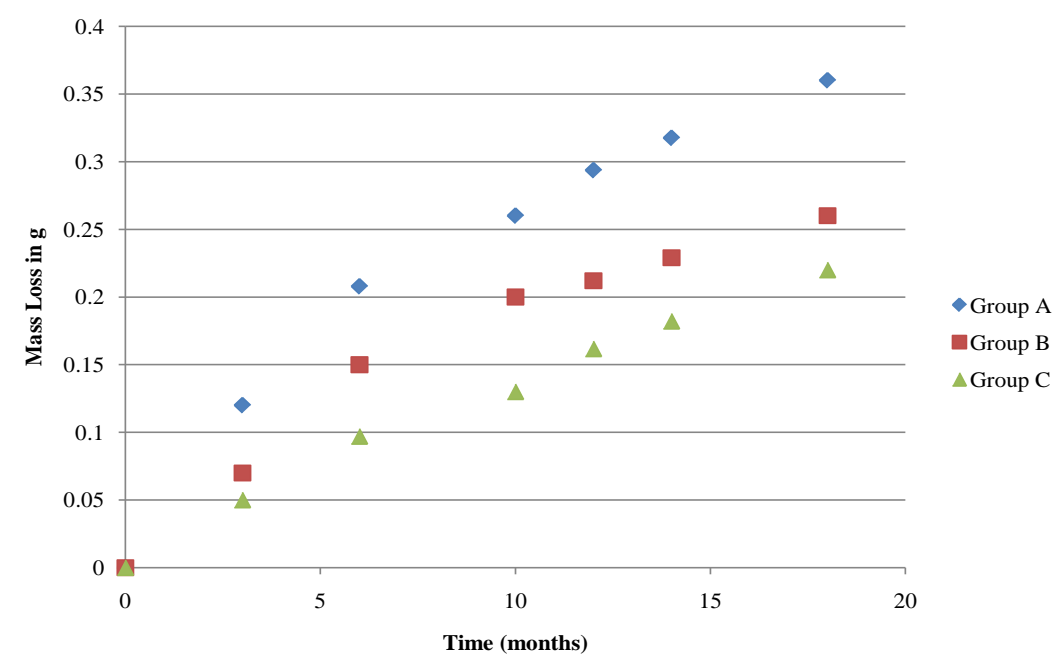

Figure 4. Comparison of mass loss of specimens of Groups A, B and C versus time.

\begin{tabular}{|c|c|c|}
\hline Group & Group A & Group C \\
\hline \multirow{6}{*}{ Compressive Strength (MPa) } & 14.5 & 14.4 \\
\hline & 14.4 & 14.6 \\
\hline & 14.3 & 14.2 \\
\hline & 14.7 & 14.5 \\
\hline & 14.5 & 14.3 \\
\hline & 14.6 & 14.4 \\
\hline Average & 14.5 & 14.4 \\
\hline
\end{tabular}

Table 3. Compressive strength of specimens of Groups A and C. 
Finally, this type of corrosion inhibitor protect as admixture into the concrete and also as sprayed corrosion inhibitor at the surface of concrete.

\section{Concluding Remarks}

Based on the results of this experimental investigation under corrosive environment, the following conclusions are drawn:

- The compressive strength is the same for all specimens.

- From the comparison of specimens, which have corrosion inhibitor with the specimens which have not corrosion inhibitor, show that the specimens with corrosion inhibitor have the tendency to protect the rebars from the corrosion. The specimens, which have the corrosion inhibitor as admixture into the concrete, have better behaviour than the specimens, which have the corrosion inhibitor as sprayed of the external surface of mortar specimens according to mass loss and electrochemical mass loss of specimens.

\section{Acknowledgements}

The authors wish to express their gratitude and sincere appreciation to the company Sintecno S. A. for free supply of materials.

\section{References}

[1] Batis, G., Kouloumbi, N. and Pantazopoulou, P. (2005) Corrosion Protection of Steel in Pumice Lightweight Mortar by Coatings. Cement and Concrete Composites, 27, 261-267. http://dx.doi.org/10.1016/j.cemconcomp.2004.02.015

[2] Kouloumbi, N. and Batis, G. (1992) Chloride Corrosion of Steel Rebars in Mortars with Fly Ash Admixtures. Cement and Concrete Composites, 14, 199-207. http://dx.doi.org/10.1016/0958-9465(92)90014-M

[3] Broomfield, J. (1997) Corrosion of Steel in Concrete Understanding, Investigation and Repair. E \& FN SPOK, London, 16-21.

[4] Basheer, P.A.M., Basheer, L., Cleland, D.J. and Long, A.E. (1997) Surface Treatments for Concrete: Assessment Methods and Reported Performance. Construction and Building Materials, 7-8, 413-429. http://dx.doi.org/10.1016/S0950-0618(97)00019-6

[5] Ibrahim, M., Al-Gahtani, A.S. and Maslehuddin, M. (1999) Use of Surface Treatment Materials to Improve Concrete Durability. Journal of Materials in Civil Engineering, 11, 36-40. http://dx.doi.org/10.1061/(ASCE)0899-1561(1999)11:1(36)

[6] Brown, M.C. (1999) Assessment of Commercial Corrosion Inhibiting Admixtures for Reinforced Concrete. Virginia Polytechnic Institute, Virginia.

[7] ELOT 142-37, Hellenic Organization of Standardization, Athens.

[8] Swamy, R.N., Suryavanshi, A.K. and Tanikawa, S. (1998) Protective Ability of an Acrylic Based Surface Coating System against Chloride and Carbonation Penetration into Concrete. ACI Materials Journal, 95, 101-112.

[9] ASTMC876-87 (1987) Standard Test Method for Half-Cell Potentials of Reinforcing Steel in Concrete. ASTM International, Philadelphia.

[10] ASTM G59-97 (2009) Standard Test Method for Conducting Potentiodynamic Polarization Resistance Measurements. ASTM International, Philadelphia.

[11] ISO/DIS 8407.3 (1986) Procedures for Removal of Corrosion Products from Corrosion Test Specimen. Genève.

[12] Gu, P. and Beaudoin, J. (1998) Estimation of Steel Corrosion Rate in Reinforced Concrete by Means of Equivalent Fittings of Impedance Spectra. Advances in Cement Research, 10, 43-56. http://dx.doi.org/10.1680/adcr.1998.10.2.43

[13] Buenfeld, N.R. and Zhang, J.-Z. (1998) Chloride Diffusion through Surface-Treated Mortar Specimens. Cement and Concrete Research, 28, 665-674. http://dx.doi.org/10.1016/S0008-8846(98)00031-3

[14] DIN EN 7783-2 (1999) Determination and Classification of Water-Vapor Transmission Rate (Permeability).

[15] Al-Amoudi, O.S.B., Maslehuddin, M., Lashari, A.N. and Almusallam, A.A. (2003) Effectiveness of Corrosion Inhibitors in Contaminated Concrete. Cement \& Concrete Composites, 25, 439-449.

[16] Fedrizzi, L., et al. (2005) Corrosion Inhibitors in Reinforced Concrete Structures Part 3-Migration of Inhibitors into Concrete. Cement and Concrete Research, 35, 551-561. 
Scientific Research Publishing (SCIRP) is one of the largest Open Access journal publishers. It is currently publishing more than 200 open access, online, peer-reviewed journals covering a wide range of academic disciplines. SCIRP serves the worldwide academic communities and contributes to the progress and application of science with its publication.

Other selected journals from SCIRP are listed as below. Submit your manuscript to us via either submit@scirp.org or Online Submission Portal.
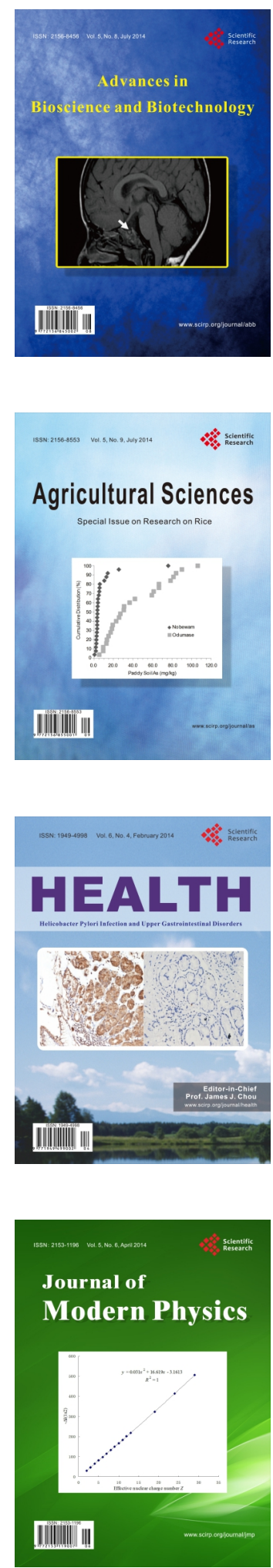
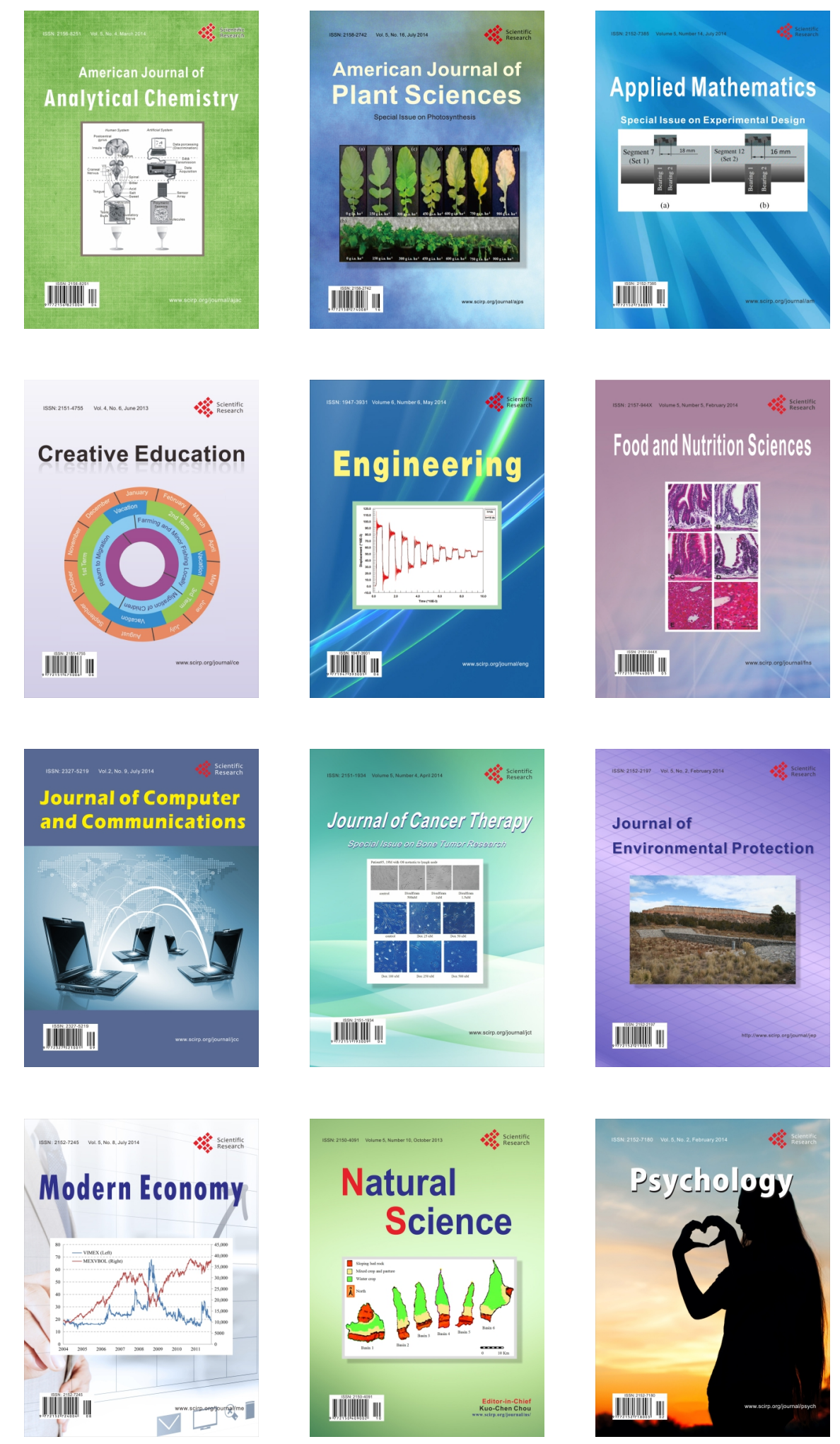